\title{
Women's access to resources: Matrilineal kinship, the patriarchal state and social differentiation in Vietnam
}

\author{
Hao Phuong PHAN \\ Institute of Cultural Studies, Vietnam Academy of Social Studies, Vietnam \\ Research Associate, School of International Development, University of East Anglia, UK
}

\begin{abstract}
This paper explores women's perspectives regarding access to resources in a matrilineal ethnic community in the Central Highlands of Vietnam. Customary matrilineal entitlements are not completely recognized by the state that is increasingly using force in asserting its ownership over forests and has a different vision regarding land tenure for households. Using predominantly qualitative methods, including in-depth interviews, life histories and observation, this study focuses on the strategies that K'ho women use to derive benefit from key natural resources such as wet rice fields and forest lands. Through the perspectives of three women of different ages, marital status and social background, I show how matrilineal kinship and conjugal relationships play out with respect to women's access to resources, given increasing state governance and control. I use an intersectional approach grounded in Feminist Political Ecology (Rocheleau, Thomas-Slayter and Wangari, 1996) and insights from Ribot and Peluso's (2003) theory of access to highlight the interactions between gender, matrilineal structures and other forms of social identities in shaping access to natural resources.
\end{abstract}

KEYWORDS Women's access to resources; matrilineal societies; intersectionality; feminist political ecology

\section{Introduction}

Access to resources, land in particular, is crucial for agriculture-based rural communities. It is now widely recognized that such access for women (and men) is shaped by kinship, marriage and social relations with state authorities and institutions at local levels (Jackson, 2003). Earlier studies have largely focused on access to resources in patrilineal communities (Rao, 2011). This paper contributes to a relatively small pool of research that focuses on women's access to resources in matriarchal communities. It does this via a case study of Tong, a Vietnamese village where the 
patriarchal state's regulation of resource use has had significant implications for matrilineal communities.

A small number of studies that focus on matrilineal communities report the growing concern of researchers about factors and mechanisms influencing women's access to land. Case studies in the Himalayas and Africa show that women's access to land in matrilineal communities is also linked to men's involvement in non-agricultural activities, through land policies and post-marital residence patterns. For example, women's relation to land and their social status in Bhutan have been influenced by its historical and socio-cultural context. According to Pain and Pema (2004), prior to the $1950 \mathrm{~s}$, men were strongly attached to monastic institutions rather than agricultural activities in Bhutan and the state prohibited land sales, whilst in the rural and remote villages land was mostly controlled and managed by women. Meanwhile, Dondeyne, Vanthournout, WembahRashid and Decker's (2003) comparative studies between uxorilocal and virilocal communities in Southern Tanzania points out that when marriages tend to be virilocal, it is more difficult for women to maintain and control their land. This is supported by Peters' (2013) study which maintains that women of matrilineal communities in Malawi have the strongest land rights within uxorilocal systems.

In the case of Vietnam, Ngo's (2015) research shows that the matrilineal Cham women have more advantageous access to land. Specifically, they are entitled to wet rice fields, gardens and residential land. In exceptional cases, men are allowed to use productive land and household assets, but they cannot inherit residential land. Moreover, they can only cultivate what is allocated to them for one generation, which is subsequently returned to their sisters or sisters' daughters after they pass away. It is significant that the strong customary inheritance practices among Cham communities have so far been able to prioritize women's access to land even after wider changes have taken place in gender relations, including those relating to land reform, in Vietnam.

This persistence of community-level matrilineal entitlements in the face of gendered dynamics operating at the national level is quite unusual. In practice, a lot of matrilineal systems in developing countries are under pressure from rapid and far reaching socio-economic changes and state-led land reform policies. Overpopulation, migration and intermarriage between matrilineal, patrilineal groups, and state-led resource governance contribute to dividing and relocating matrilineal clans spatially, sharpening social differentiation among matrilineal households, loosening traditional systems of customary access to land within the community, and adopting new systems which might be more male-biased and thereby less beneficial for women's access to land (Phan, 2018). Therefore, contemporary research on women's access to resources in matriarchal 
communities needs to examine both ongoing structural dynamics as well as the diverse strategies adopted to secure resource access in the context of such changes. Doing the latter involves not only examining the strategies of married women, but also investigating how poor women and widows, who are more likely to be invisible and marginalized in state and non-state development programs, strategize to improve or secure their access to resources (Rose 2003).

Accordingly, this paper investigates the complex case of women's access to resources in the matrilineal community of K'ho within the patriarchal Vietnamese state. Unlike the Cham, the K'ho in the Central Highlands of Vietnam have been in close contact with other patriarchal groups, mainly Kinh people, through migration and interdependent economic relationships, therefore, their matrilineal patterns of resource access have come under considerable pressure to change. By presenting the life histories of three women from different social backgrounds in Tong village of the Central Highlands, this paper addresses the key factors that influence local women's access to resources and how their strategies to do so are contingent on gender, socio-economic status and household dynamics.

In the following sections, I first introduce the theoretical and methodological approach of the paper. I then provide a brief overview of the research site in terms of its geo-political location, its patterns of resource access and governance, and its social differentiations. Next, I present the main data for this paper, the three contrasting life histories, and draw on these to understand women's strategies to access resources in matrilineal societies and the emerging conflicts relating to this. Finally, I conclude that while women of matrilineal communities in the Central Highlands of Vietnam can still rely on matrilineal-based ties for resource access, the increasing commercialization of forest land and the penetration of patrilineal-based systems of governance pose challenges for them in asserting their claims both within their households and community.

\section{Theoretical and methodological approach}

\section{Theoretical approach}

In this paper, I adopt an intersectional approach grounded in Feminist Political Ecology (Rocheleau, Thomas-Slayter \& Wangari,1996; Elmhirst 2011a) to look at women's access to resources in matrilineal societies. Intersectionality perspectives view race, gender, class and ethnicity as interdependent rather than exclusive social categories (Crenshaw 1989). Therefore, applying such an approach helps to address the complexity and inclusiveness of research on gender, (in)equality and (in)justice. This paper focuses specifically on women's viewpoints and the means, processes and mechanisms they use to access resources. It offers a comprehensive look at these through a 
study of a matrilineal community that relies on agro-forestry activities as their main sources of livelihood. The social structures, inheritance patterns and main sources of household income in this community illustrate differentiated mechanisms of resource access for women, which differ from those of patrilineal communities. This paper, therefore, contributes to the current debates of the proponents of feminist political ecology (FPE) (Elmhirst 2011b, Nightingale 2011, Truelove 2011) regarding how gender interacts with other forms of social differentiation such as ethnicity, age, social status and culture in shaping resource access, and control.

As this paper focuses on a matrilineal case within a patriarchal state, I also draw on Ribot and Peluso's (2003) theory of access to analyze how the state exerts influence on local communities. As these authors point out, local access to resources is conditioned by rights-based mechanisms, which include both legal and customary rights. So, I seek to illustrate how matrilinealbased customary and legal rights are played out, and how certain actors manage to deploy their customary and/or legal rights while others cannot. I also attempt to understand how and why certain elements of customary rights are not necessarily recognized as legal and vice versa.

This paper contributes to the literature on women and resource access in two ways. Firstly, it is among the few attempts to theoretically operationalize Ribot and Peluso's theory of access within the overall framework of FPE. It illustrates that combining the theories of access and FPE can usefully capture the dynamic interactions between individual circumstances, local norms and national frameworks and how they shape women's decision-making with respect to resources. Secondly, the paper explores how these diverse and changing strategies to access resources have implications for how policies pertaining to these, as led by a patriarchal state, work out in practice. This contribution has particular relevance for matrilineal communities nested in patrilineal states in Vietnam and Southeast Asia.

\section{Methods}

Methodologically, I rely mostly on qualitative data such as in-depth interviews, life histories and field observations. The main data for this paper was drawn from a larger body of ethnographic research conducted from May 2015 to January 2016 in Tong Village, in the Central Highlands of Vietnam. During this time, I undertook in-depth interviews with local villagers, authorities and forest officers. These provided me with basic information about the village such as its history of settlement and resettlement, inter-ethnic relations, and traditional forms of land and forest access. In 
addition, I recorded fourteen life histories, of which three represent the primary data for this paper. I also utilized my field observations for deepening insights into existing social relations and negotiations in the village and how they impact women's access to resources, as these issues are difficult to investigate merely through discussions or face-to-face interviews.

While this paper is based largely on empirical data collected locally, my study links these to national frameworks/actors in order to examine their interaction with local ones. This is because the history of the village and resource management here is not only about local people and institutions, but is also shaped by wider socio-economic and political projects. These national-local dynamics have contributed to transforming Tong village from an isolated indigenous settlement within the old forests into a homogenous community which is seen by the state and NGOs as ideal for piloting community forestry schemes. In this paper, I have tried to situate local actors, i.e., three K'ho women of different backgrounds vis-a-vis their local norms and the national framework of the Vietnamese patriarchal state. I studied local/national actors in order to record what they actually responded to, how they mobilized support from and/or were constrained by these complex institutions and relationships. By using the three cases I seek to illustrate how marital status, availability of matrilineal support networks, age and socio-economic status are linked to these women's strategies to access land.

A focus on women's strategies and life histories is methodologically useful for the following reasons. Firstly, a focus on women's strategies enabled me to go beyond the common narratives of "the average women" or "the married women" (Rose 2003), and include other groups of women in my research, for example, poor or divorced women. This helped address two questions: one, whether traditional matrilineal structures still help to protect women's interests in the context of a matrilineal society in transition and, two, if so, how women's experiences and social identities differ. Secondly, focusing on women's strategies enabled me to understand how local women actively mobilized support and maximized their households' access to land. This was especially relevant for the concerned community, where women's experiences and choices were often related to and represented by their male counterparts. Thirdly, a focus on women's life histories also reflected my data collection strategy, as I found it challenging to record these for local men in the same way as I did for local women. To tackle this limitation, I sought to provide a partial account of access to land and supplemented it with my field observations of how these gendered dynamics actually worked in the village. 


\section{Research context}

Tong village is formed out of two villages, namely So and Reng, and a cluster of households from the Ye clan who used to live isolated in the forest. The ethnic composition of Tong was quite homogenous. Of 217 households (in 2015), only seven were from the Kinh community (the majority group in Vietnam) and the rest were K'ho, which is the biggest ethnic minority group in Lam Dong Province and has several sub-groups such as Lat, Noup, Cil, Dala, Sre and Ma. The word K'ho is said to come from "Kahow," which was used by Cham people to refer to an indigenous group who spoke Mon-Khmer languages and lived in the forest (Phung, 1973). Local people in Tong belonged to the Sre sub-group, which literally means people working in the wet rice fields. They are organized under different matrilineal clans or Kon in the K'ho language.

The name "Sre" suggests that K'ho people in Tong were among the first Montagnard (people of the mountain) communities to grow wet rice in the Central Highlands. My empirical data, meanwhile, shows that historically the K'ho practiced both shifting cultivation (of indigenous hill rice) and fixed farming (of wet rice). Specifically, local communities cleared forest land on slopes and moved around to find new paddy fields every three to five years. They also cleared forests in valleys where the land was flat and close to main water sources in order to plant wet rice. Before the Vietnamese Reunification of 1975, Tong villagers could freely access forests for shifting cultivation although their access was strictly governed by K'ho customary laws.

\section{Local resource access and governance}

After 1975, as part of Vietnamese nation-building efforts and forest management projects, forest lands were placed under the state forestry agencies and in the villages, agricultural lands were collectivized. The latter officially ended in 1988 and agricultural lands were redistributed to individual households for farming. By the early 2000s individual households were allowed to register their agricultural and residential lands through the land titling schemes and they received land use certificates. Meanwhile, the hill paddy fields of Tong villagers were also converted into coffee plantations during the early 1980s when the coffee boom arrived in the Central Highlands. To maximize areas for coffee plantation, local people continued to clear forests plots. Nowadays, apart from a small area of paddy fields classified as "agricultural land," because of its location with respect to wet rice fields, most of it is categorized as "forest land." The state's claims to forest land effectively exclude local people from living and farming on certain lands which customarily belong to them. 
In order to develop alternative livelihoods and reduce pressure on forests, in 2011 Tong villagers were allocated 500 hectares of forests for protection, and each household participating in the village forest protection groups received the same amounts in quarterly payments. Apart from those 500 hectares (also known as a community forest), most of the forested areas in the region are legally owned by a state forest company (RECOFTC, 2014). This company selects a small number of households in Tong village and signs forest leasing contracts with them. According to these, the company-owned forest land is allocated to selected households for protection and, in exchange, the company pays them a set amount every three months.

In terms of productive land, local people utilize both wet rice and coffee lands. In this paper, I discuss both of these that are currently accessed by local people, legally and illegally, so long as they still continue to grow and harvest on these lands. However, due to the complex relations regarding land and forests in the research site, I focus on "access to resources" rather than merely "access to land" in order to acknowledge the coexistence of different understandings of tenure. These different understandings lie at the heart of the dynamics of the contemporary use of resources in the village: while the state sees its tenure over forests as fixed in order to set rights to access resources on this land, customary understanding of people sees the clearing of trees and planting and tending of coffee trees, or earlier wet rice, for establishing and maintaining their rights over these. In other words, in the state view, ownership determines resource use while in the customary view resource use creates ownership.

\section{Social differentiation and change}

As this paper attempts an intersectional analysis of women's access to resources, it is important to address the major axes of social differences in Tong village. These included wealth, status, ethnicity, gender, marital status, age, and I will discuss these and the dynamics such factors pose. The main sources of income for most K'ho households, as mentioned earlier, are from agriculture-based farming and their work for forest protection. Local people normally refer to the area of productive land (mostly wet rice fields and coffee plantations) owned and accessed by a household as the most important criterion to determine its economic status. According to the report by RECOFTC (2014) and my empirical data, an average K'ho household in Tong village owns up to one hectare of a wet rice field and one hectare of coffee land. Following this criterion, a rich household owns more than a one hectare each of wet rice field and coffee land; and a poor household owns less than that. While wet rice fields tended to become smaller after being divided among daughters, coffee plantations were expandable (mostly in illegal ways), and more expensive. However, the need to 
secure rice for household consumption and partly to secure the very "root" of matrimony (inheritance of wet rice fields by women/daughters) was one of the reasons regarding local perceptions of "richer households owning larger wet rice fields." Moreover, a household can still be considered rich if it has less than a one hectare wet rice field and a lot of coffee land (up to two hectares).

There were other criteria used by local people to categorize households such as if the household's member(s) held a position in the commune-based people's committee, had salaried jobs in local institutions such as local schools or clinics, owned a multi-storied Kinh-styled house (a concrete house with separate bedrooms, toilet and kitchen), or had no outstanding debt following earlier investments on crops. From a local perspective, a household that could be assessed as per any one of these four criteria was rich or financially stable. During my stay in the village, as a Kinh outsider and member of a government research institute, I was placed in the rich household category. The three host families I stayed with had more than a hectare each of wet rice fields and coffee lands; they also fulfilled two of the other criteria. All, except one, households in the village had outstanding debts from earlier crops. Indebtedness was so common that even rich households struggled with cash flow and daily expenses. Poverty was experienced on a daily basis in the village and has grown due to indebtedness and high interest rates.

Tong was among a few villages in the region where K'ho people made up more than 95 percent of their total population. There were only two households with intermarried couples and five other Kinh households that were temporarily there, running small businesses. Due to these specific demographic characteristics, ethnicity did not play a role in differentiating access to resources between K'ho and Kinh households. Moreover, local K'ho households in Tong were less inclined to adopt Kinh and patrilineal systems of resource use and management, which partly explains why matrilineal gendered norms of resource access continue to be practiced. Typical scenarios of local access to land for married women and men were as follows: (1) women inherit wet rice fields from their mothers; (2) residential land also belongs to women, mostly because in matrilineal societies, men move into the houses of their wives and wives' families after marriage; (3) coffee land, as part of home gardens (attached to residential land) or what were previously hill rice fields, was reserved for women. Apart from traditional norms regarding access to land/forest, I observed some new emerging patterns of access to resources linked to marital status and age. For example, divorcees and widows normally had secure access to wet rice fields and residential land, but not to coffee land. Moreover, access to resources for the younger generation was slightly different from what it was for the older generation. This was because many unmarried men often 
looked for forest land in order to convert it into coffee plantations. So, when they got married, they would bring some coffee land with them and continue to work on it with their wives and sometimes their wives' siblings (Phan 2018).

\section{Accessing land: Three women's life histories}

In my conversations with local women in Tong village, including the three I chose for my case studies, they often said that they feel more secure with their natal families and female siblings. For them, the matrilineal-based arrangements gave them better access to their wet rice fields and coffee plantations, especially if their mothers gave these to them from within their home gardens and also supported them in child rearing. In the following sections, I briefly introduce the socio-economic backgrounds of the three women and their different resources.

\section{The case of Mrs. KD}

Mrs. KD was my third host in the village. She worked for the Commune People's Committee for several years and received a monthly salary. As a divorcee with four children aged between 18 to 32 years, she shared the house with her youngest son and her eldest daughter's family. She was the head of the household and therefore made most of the important decisions relating to finance and property. Her oldest daughter, son-in-law and youngest son worked together on their separate plots. Each of her two daughters were given wet rice fields and coffee plantations after marriage, while her two sons, including the youngest one, were given plots for cultivating coffee. She kept a piece of land for herself and worked on it with the support of her oldest daughter.

When she had married Mrs. KD, along with her ex-husband, worked on the wet rice field, given by her mother. The couple cleared a plot of forest land (around 0,8 hectare) for planting coffee. This became the shared property of husband and wife, together with the house she and her youngest son lived in. After she split up with her husband, she gave him half their coffee plot and his share of their matrimonial house. As per traditional customs, she kept all her children and raised them by herself. When they were small, she ran a small provision shop in the village that gave her an income. She borrowed money to convert a shed into a concrete house and sent her three children through college. Although she received a monthly salary after she started working at the Commune People's Committee, the main income for her household came from her children's coffee plantation. Apart from the plantation that Mrs. KD and her husband used to work on together while they were married, she did not get access to any other land for cultivating coffee from her husband. However, she managed to buy some wet rice fields from her friend, in exchange for a small amount of money, 
and therefore continued to take care of her friend and his family members. She also worked as a part time nurse and earned small amounts by giving injections to people in the village. According to her:

For the wet rice field, I only paid 10 million VND (approximately 500 USD), because I bought it from one of my friends. I gave him 10 million VND, and I took care of his children for him and when he was sick, I also gave him injections for free (Mrs. KD, personal communication, August 14, 2015).

Mrs. KD at the time was looking to buy forest land in nearby villages, via her personal networks, to convert into a coffee plantation. Her daughter, who was currently cultivating her new plantation, had sold her old one as she did not have enough labor to maintain it. Her wet rice field belonged to her, as per custom, but it was registered in her and her husband's names in the red book or land registration certificates when they married. According to her, customarily the field was hers, and her husband or in-laws will not be able to take it from her. It is widely said that land disputes were never a serious problem in the village. However, her own experience of marital breakdown and role in the women's union had led her to rethink the current practice of land titles in the village:

If the land laws are changed, the wet rice field should be registered in the woman's name because it belongs to her. The wet rice field can't be registered in the man's name. Only the land that both husband and wife clear together [after marriage] can be registered in the couple's names (Mrs. KD, personal communication, June 8, 2015).

\section{The case of Mrs. KE}

A middle-aged woman with two teenage daughters, Mrs. KE openly talked about her poverty with her neighbors and relatives. Her household was considered poor as they had little wet rice land and could not grow enough rice for daily consumption. She only received a tiny wet rice field from her mother when she married. Her husband was from the same village as her, but her parents-in-law had no daughters. Technically, the wet rice field of the latter's family should become the shared property of her husband and his one brother. However, Mrs. KE's brother-in-law was married to a woman from another village and worked on the wet rice fields of his wife's family. According to her, he was therefore, not in need of productive land as much as they were. She was given a low-interest loan by the state as her household was poor and qualified for state financial aid. While it was locally known that she and her siblings had the smallest wet rice field in the village, some people said that 
she and her husband could access the wet rice fields from her husband's family and so they should not have received state financial aid. In response, she said:

If we tried to grow rice on my parents-in-law's field, my husband's relatives would talk badly about him. They would say that my husband got married already so he should have relied merely on my and my family's wet rice field (Mrs. KE, Personal communication, January 12, 2016).

Despite such gossip by Mrs. KE's husband's relatives, they decided to approach her parents-in-law for help. In turn, they knew that they would have to shoulder the responsibility of taking care of her parents-in-law and, when they passed away, pay the funeral costs, which may cost up to 100 million VND (about 4,700 USD). This meant that they would have to borrow money from money lenders and pay them back after selling their coffee produce. However, as she said, if she could not fulfill such responsibilities and expenses, her husband's relatives would take back the wet rice field they depended on now.

She had around 0.8 hectare land from her mother and her husband had 0.1 hectare from his family on which they grew coffee. These plots were on the hill and technically classified as forest land, therefore, they could not register for an agricultural land use certificate and get a loan directly from the bank that would require these as collateral. However, as mentioned earlier, her household was classified as poor and therefore she had received a low-interest loan. Being classified as such also facilitated the participation of the couple in forestry projects. As one of the main purposes of such projects in Tong village was to help poor households with sufficient labor to participate in forest patrolling groups and earn extra cash, her husband joined the group for one year during which they received quarterly payments from the state forest company.

\section{The case of Mrs. KH}

My third case study was of Mrs. KH, a woman who was slightly younger than the other two. Her husband was from another village and the couple had two young children who she took care of with the help of her female siblings. She and her husband bought her house about five years ago. Previously, they had lived near their wet rice fields with her parents outside Tong village, but moved here because the infrastructure there was inadequate. At the time, her parents did not have any residential land in the village to give her, so the couple borrowed five million VND (220 USD) from her husband's family and bought a small plot of land (around 0.03 hectare) to build their house. Although she did not inherit a residential plot like the other K'ho women in the village, Mrs. 
$\mathrm{KH}$ received a 0.2 hectare wet rice field and 0.1 hectare coffee plantation from her family. Further, the couple also received 0.5 hectare land for growing coffee from the man's family and he owned a coffee plantation of 0.15 hectare in a nearby village. She said: "If I had married a man from the same village, I would not have had any land to plant coffee, because it's too crowded here." (Mrs. KH, Personal communication, October 27, 2015). Her family coffee plantation, jointly owned by husband and wife, included both non-registered and registered plots. The latter were classified as agricultural lands because according to the local forestry officers, they were located near the wet rice field and flat enough to be used for rice cultivation. Besides, a small part of their coffee plantation was officially registered in the names of her parents-in-law. The rest was classified as forest land and was not officially registered.

Mrs. KH described the long procedures they undertook from the time they occupied the forest land, cutting down trees, and converting it into a coffee plantation:

It's very tiring to work that land. There was not much soil, only big rocks. We had to dig at least 40 centimeters to remove the rocks and then, we could see the soil and plant coffee plants...At first we planted 100 plants per year. We didn't plant too many during the first year, because they [the forestry officers] threatened us with guns...

Last year we planted 30 more coffee plants, but the forest officers uprooted them. This year, maybe we will just work on half of the land and leave the rest empty, because we have no money to buy plants. We still keep the big coffee plants, because I heard that they would not remove coffee planted before 2004. Those who had planted these after that (as of 2015) have had their plants removed (Mrs. KH, Personal communication, January 12, 2016).

According to Mrs. KH, she helped her husband in most of the physical work, except for removing and carrying the rocks. She also noted that they invested a lot of time and energy working on the illegally converted coffee plantations and sometimes she had to engage directly with local forestry officers to protect their rights to access this land.

\section{Discussion}

This discussion focuses on how the three women accessed land and forests, what strategies they deployed in order to maintain access to these, and finally how they perceived their gendered roles with respect to these. It examines the various conflicts they faced in obtaining and maintaining access to agricultural and forest lands at the household and community level. It also situates these 
conflicts within the broader socio-political and economic contexts of resource access in the Central Highlands and highlights the impact of the patriarchal state on matrilineal customary entitlements.

The life histories of the women firstly reveal how K'ho women gained access to resources through conjugal relationships, matrilineal kinship and relationships with local authorities. A divorced woman like Mrs. KD, who could not rely on a conjugal relationship to access necessary land and labor, had to reach out to fictive kinship relations to do so. Forging "kinship" or "sentiments" has been identified as a strategy of migrants to secure land access elsewhere in the Central Highlands (see Hardy, 2000; Hoang \& Nguyen, 2013). For a local villager like Mrs. KD, these processes helped her build up her and her children's access to coffee plantations. It is noted that the type of land she sought to buy from her acquaintances was mostly forest land because conversion into coffee plantations was not allowed. Nonetheless, she took the risk of "buying" it as it was originally claimed by someone else she knew and presumably trusted. It was also more affordable for her to buy this type of land due to its unofficial status. She claimed that when she first did so, the area was still forest and her children had to clear the trees and plant coffee on it. This kind of land transaction, to Mrs. KD and local people in Tong village, was acceptable so long as the state or local authorities did not question her and allowed her to plant coffee on it. In her case, the possibility of being questioned by local authorities was minimal as she still held a position in the local government and maintained strong political connections with the important authorities. As a result, she had an advantage over other villagers in her access to the land and forest.

Married women like Mrs. KE and Mrs. KH, with fewer socio-political and economic resources, sought to utilize the available resources and support of their husbands' families to extend their access to land. For Mrs. KE, gaining access to the wet rice field from her husband's family was her main strategy. Although traditionally only women can inherit wet rice land, there have been several exceptional cases where men like her husband have inherited wet rice fields in Tong and neighboring villages. So although this case was unusual, it was not without precedent. In my conversation with her, I could understand how she weighed up the pros and cons of using this strategy. Having access to wet rice fields from her husband's family would help reduce her concern about food security and build up a savings fund for her daughters. However, it would mean dealing with the financial burden of supporting her ageing parents-in-law that was associated with her husband being a wet rice field heir.

Meanwhile, Mrs. KH sought access to land through inheritance and her conjugal relationship with her husband who was from a different village. In this case, kinship and conjugal relationships played equally important roles in women's access to land. Mrs. KH herself realized 
the benefit of marrying a man from a different village where the land was still abundant and easy to access. Being a young couple, she and her husband were also more active in searching for forest land to convert into coffee growing land. Like Mrs. KD, they were aware that their coffee plantation was on forest land and the forest officers may subsequently remove them. However, as they did not have strong political connections with local authorities, they sought to minimize damage and avoid being caught by the forest officers. For example, after their coffee was confiscated several times, they started planting another short-term crop, together with coffee to divert the attention of the forestry officers. Alternatively, they chose to leave the land unoccupied for several years after their coffee had been confiscated. This strategy required more labor and capital investment for planting and replanting coffee, which Mrs. KH could afford with the support of her husband and his family.

The contrast between the strategies of Mrs. KD and Mrs. KH to extend access to coffee growing land and dealing with the local authorities was striking: while the former managed to reduce the risk of losing her illegal coffee plantations through her political connections, the latter resisted the local authorities silently. This is similar to Rose's (2003) findings regarding women in Malawi whose strategies for accessing land varied according to their political connections with local authorities and/or their social status. Conceptualizing the different strategies used by the women she studied as manipulating, challenging, or changing the customary rules of land access, Rose noted that that they chose to manage both with and without the support of the authorities. Applying her typology to my case, Mrs. KD's mobilization of the support of local authorities was a kind of manipulation while Mrs. KH deployed challenges that were normally non-confrontational and invisible.

The life histories of K'ho women in Tong village, as seen earlier, uncovered the crucial role of social ties and relations in access to land. This resonates well with earlier research on women's land access in Africa and South Asia (Berry, 2002; Agarwal, 2003; Jackson, 2003). Berry (2002, p. 651), for example, notes that in Africa, "even poor women and men fought to retain, at least in principle, the possibility of gaining access to land through social ties of one sort or another." Among these, social ties, conjugal relationships, kinship and women's groups, as she points out, are the main channels through which women sought access to land. Agarwal (2003) and Jackson (2003) reported similar findings in the case of South Asia. However, there are fundamental differences between earlier research findings and my case studies: most of the former have been conducted in patrilineal and patriarchal systems where women only have "secondary land rights" (Stanfield, 1984). In these circumstances, if women want to claim primary ownership rights to land, they have to challenge inheritance rules. Meanwhile, in Tong village women have customary rights to wet rice 
lands and coffee growing lands and can potentially extend their land access through conjugal relationships or socio-political connections. However, I note that in my research, most women resided in their mothers' villages, including Mrs. KH who was married to a man from a different village. Therefore, they worked on parts of their mothers' lands and their customary rights to these were more secure.

The reliance on social ties to gain access does not necessarily come without cost. Following the everyday struggles of local women to access resources, we can understand how potential conflict over resources can scale up from the intra- and inter-household level to the community level. In the case of Mrs. KD and Mrs. KE, conflict arose out of disagreements between spouses, or between the couple and other kin members regarding access to wet rice land. Traditionally, such land is reserved for women so it remains within the matrilineal clan. This tradition of land inheritance leads to conflicts between son(s) and other female kin members of the clan when son(s) also claim their rights over wet rice fields in the absence of daughter(s)/female siblings in their families. In Mrs. KE's case, her access to land was conditional, based on her ability to fulfill her traditional duties towards her ageing parents-in-law. Failing to fulfill these may lead to conflict in her extended family. In short, such conflicts were land-related and went beyond her household as they involved other female kin members of her husband who may then be entitled to the wet rice land of her parents-in-law as per K'ho tradition. This was similar to Peters' (2002) observation of land conflicts among female siblings, where women in a matrilineal community in Malawi insisted on fighting their sisters for rights to land, even though it would potentially lead to breakdown of their kinship ties.

The tradition of inheritance within matrilineal societies was further complicated by the patriarchal-based land use certificates. In other words, the mismatch between matrilineal customary rights and patriarchal legal rights may result in certain disputes at various levels regarding access to land and forests. In this case, a discussion about women's strategies for gaining access to land is not limited to the local level, but may extend to the national level as well. Mrs. KD's case was a typical example of how patriarchal legal rights can influence women's access to land in a negative way. While K'ho traditional systems of land inheritance aim to protect women's claims over wet rice fields, in case of marital breakdown, state institutions, in this context via the red book, do not necessarily take this into consideration. Apparently, there is potential for conflict between those who customarily own wet rice fields and those who are recognized as official owners of wet rice land in the certificates and may ultimately impact the intimate context of the household. Although in Mrs KD's case, and in Tong village generally, customary rights of women over wet rice fields are 
still widely respected, the gap between customary practice and laws should have been more appropriately addressed in the national legal system to avert conflict over land at the household level.

Mrs. KH and her depiction of how young couples in Tong village attempt to convert forest land in the hills into coffee plantations, meanwhile, reveals another type of conflict that goes beyond household or community levels. This involves local people and forest officers/rangers who are in charge of managing and protecting forests and those who represent the state and patriarchal legal rights in the village and beyond. When couples are caught planting coffee on forest land or clearing small plots to plant coffee, it is usually the woman, rather than the man, who does the talking with the male forestry officers. According to Mrs. KH, K'ho women can deal with these forestry officers better than men. By reproducing certain social stereotypes about women of certain ethnic groups to position themselves with respect to the forestry officers, they often manage to escape penalties for violating the forest laws. During unexpected encounters with the forest officers (mostly male and lowland people), Mrs. KH was challenged by people from outside of their community. She strongly believed that her household deserved to get the land for coffee growing because they work on the land by themselves. Her resistance to state laws, although subtle, points towards the tension between the local and national actors in perceiving legality and illegality. As such, coffee plantations on previously held forest land was considered illegal by the state, yet it was seen as legitimate by local people, who referred to their customary entitlements for expanding their sources of income.

In Tong, conflict relating to resource access, especially between local people and outsiders, reflect the broader socio-cultural and political context in which they take place. Except for Mrs. KE, the two other women paid a great deal of attention to building and maintaining access to land for coffee plantations. As I have noted, in the wake of the coffee boom in the Central Highlands since the 1990s, these are considered the most valuable means of production. In Tong, however, such land has not been officially registered and the coffee plantations have been bought and sold informally without papers by local people over the last decade. In some cases, these processes start with one family member occupying the hill and mobilizing his/her siblings and relatives to convert it into a coffee plantation. Alternatively, two parties agree to buy and sell a piece of the forest in an area that is not strongly controlled by the state forestry agencies, after which the buyer can clear the trees and establish her/his customary ownership over it.

As state control over forest land in the Central Highlands and in Tong village was wellestablished, local villagers had difficulty finding unoccupied forest land to convert into coffee 
plantations. Therefore, they increasingly rely on kinship and conjugal relationships to maintain and extend their resource access. Sharecropping and work-sharing arrangements are still preferable among relatives as means of mitigating risk and maintaining channels of access to resources. For example, before taking the wet rice field from her parents-in-law, Mrs. KE worked as a sharecropper with them to supplement her and their household rice consumption. Mrs. KH and her husband's family also exchanged labor when they occupied the hill and cleared the forest. They started working on their own plots only after the forest was cleared and the land divided and ready for conversion into coffee plantations. Apart from work efficiency, these work-sharing arrangements help them to cope better with the risks of being caught by the forest officers/rangers, as well as protect their plots from other villagers who are also looking for land.

By examining the everyday struggles of local women to access resources, this paper also illustrates how women of matrilineal groups deal with patriarchy at various levels. Within the household, men still get their say in important decisions such as buying and selling land or whether to occupy certain plots of land. This is because local K'ho men bring in land for coffee growing, which is a more valuable resource after marriage. Local $\mathrm{K}$ 'ho men also are the main ones who provide the labor to work on the land, as evident in the case of Mrs. KH, and their control over more valuable land gives them higher status. Meanwhile, women are left with only wet rice fields to ensure food security for their households and their daughters' welfare.

Outside the household, patriarchy is experienced through the domination of men over important institutions such as forest patrolling groups, community forest management committees and state forestry agencies (forestry officers). These men played an important role in deciding whether certain plots of illegally converted coffee land could be accessed by women and their households. For example, Mrs. KH struggled to keep her coffee plantations because she had no connection with local authorities and forestry officers. Therefore, when she was caught working on the coffee plantations, she was threatened by these men and ended up "begging for their sympathy" in order to keep her coffee. Outside the household, patriarchy is also experienced through patriarchal land laws that seek to bring gender equity to land access through the co-registering system of land titles. As I noted earlier, the idea of gender equality in land access is imposed by the state but goes against the core principle of matrilineal systems, evident in the case of Mrs. KD. This works in particular against women who are separated or divorced from their husbands but are interested in keeping their customarily-owned land. Looking further, these patriarchal land laws are part of the Vietnamese state's strategy to systematically dominate women, both in their domestic 
and public spaces. Although in my respondents' narratives, they rarely spoke about state patriarchy, they did experience it on a daily basis.

\section{Conclusion}

The three life histories I use here illustrate that the strategies pursued by the women were not random; rather they were embedded in and emerged from intersectional relations of power within their socio-economic contexts. Aiming at virtually the same goal of expanding coffee plantations, and securing certain areas of wet rice fields, women made decisions based on their age, marital status and social position. From my case studies, certain patterns emerge: (1) younger women tended to choose their future partners with certain ideas about potential land access and how they could afford to clear more land for coffee cultivation which the older women could not; (2) married women could access land through their husbands' families, while divorced women could not. The latter either had to rely on personal networks to expand their coffee production or rely on their adult children to work the land; and (3) women of higher social status negotiated with local authorities better while poor and marginalized women had to undertake resistance or use "nice-talking" skills to maintain land that was illegally acquired through encroachment. While I have chosen to focus on three case studies for this paper, these patterns are also based on my observations of how other women in Tong typically think and act with respect to land. My study shows that the dynamics of matrilineal resource access in this context, where rapid socio-economic change and a patriarchal state are increasingly impinging on village life, are complex. Further it shows that there are important differences in resource access between women of matrilineal communities and the contemporary dynamics that are in a state of tension with matrilineal inheritance. This can have varied implications for different women. Therefore, it is important for studies of women's changing access to resources in matrilineal communities to pay attention to both women's varied social and intersectional identities and their agency for navigating their positions to improve or secure resource access.

I have specifically focused on the strategies of ethnic women in their everyday struggles to derive benefit from agricultural and forest land. These highlighted the role of kinship and conjugal relationships in women's access to resources in a matrilineal community where women's access to resources is different from those in patrilineal societies. This builds on previous studies regarding land access and adds details regarding the differences among women. Through an intersectional approach, grounded in feminist political ecology and Ribot and Peluso's theory of access, this paper has noted the intersecting aspects of gender, age and social status in shaping women's access to 
resources and addressed the gaps between matrilineal customary rights and patriarchal state laws regarding resource governance. It has noted how gender relations and cultural norms may work against women in terms of their access to resources across varied levels, and how they mobilize these social relations and ties to gain access to land (Peters, 2002; Berry, 2002; Ossome, 2014).

This study contributes to understanding the changes experienced by contemporary matrilineal communities situated within patriarchal states. These are somewhat understudied, particularly in the context of Southeast Asia and in transitional societies. My analysis of Tong shows that although there has been a transformation of social structures and relations, given the influence of a market-oriented economy and the coffee boom in the Central Highlands, competition over resources among matrilineal kin is not the main issue. Rather, the key problem is, and has been since the Reunification of 1975 , that the competition over resources between local people and outsiders who represent the (patriarchal) state and who attempt to impose legal structures of resource management on top of local traditional (matrilineal) ways of land inheritance and use. The study shows that both K'ho women and men see the main problem as one of gaining access to resources in the face of pressure from outsiders and the state-led reforms. This suggests that rather than being eager to seize the opportunity to weaken matrilineal resource access, K'ho men also have strong interests in its continuation. However, future research is needed to understand how men within matrilineal groups can exercise greater patriarchal control, and how their gender-based strategies might be different or similar from those of women.

\section{Acknowledgement}

My research was made possible with the generous support from the 'Conflict and Cooperation over REDD+ in Mexico, Nepal and Vietnam' project [funded by the Netherlands Organisation for Scientific Research and the UK Department for International Development, grant number W07.68.415] and the 'REDD+: the forest grab of all times? [funded by the Danida Fellowship Center, grant number 13-08KU]. I was also supported by the Korea-ASEAN Collaborative Research Project funded by the ASEAN-ROK Cooperation Fund to write up this paper. All errors remain my own responsibilities, and do not represent the viewpoint of these organisations or funders.

\section{Notes on contributors}

Hao Phuong PHAN (Ms) has a PhD in International Development from the University of East Anglia, UK, and MA (by Research) in Southeast Asian Studies from the National University of 
Singapore (Singapore). She is currently affiliated with the Institute of Cultural Studies (Vietnam Academy of Social Studies) as a researcher. Her research interests in gender, environment, and development have led to her active participation in the Global Environmental Justice group at the University of East Anglia and the Asian Association of Women's Studies. Email: phanphuonghao@gmail.com

\section{References}

Agarwal, B. (2003). Gender and Land rights Revisited: Exploring new prospects via the State Family and Market. Journal of Agrarian Change, 3 (1-2), 184-224. https://doi.org/ $10.1111 / 1471-0366.00054$

Berry, S. (2002). Debating the land question in Africa, Comparative Studies in Society and History, 44(4), 638-668. https://doi.org/10.1017/S0010417502000312

Crenshaw, K. (1989). De-marginalising the intersection of race and sex: A black feminist critique of anti-discrimination doctrine, feminist theory and antiracist politics. The University of Chicago Legal Forum, 1, 139-167.

Dondeyne, S., Vanthournout, E., Wembah-Rashid, J. A. R \& Deckers, J. A. (2003). Changing land tenure regimes in a matrilineal village of Southeastern Tanzania, Journal of Social Development in Africa, 18 (1), 7-31. http://dx.doi.org/10.4314/jsda.v18i1.23817

Elmhirst, R. (2011a). Introducing new feminist political ecologies. Geoforum, 42 (2), 129-132. https://doi.org/10.1016/j.geoforum.2011.01.006

Elmhirst, R. (2011b). Migrant pathways to resource access in Lampung's political forest: Gender, citizenship and creative conjugality. Geoforum, 42 (2), 173-183. https://doi.org/10.1016/ j.geoforum.2010.12.004

Hardy, A. (2000). Strategies of migration to upland areas in contemporary Vietnam. Asia Pacific Viewpoint, 41 (1), 7-21. https://doi.org/10.1111/1467-8373.00104

Hoang, C. and Nguyen, Thi P. C. (2013). Một con cá rơi vào giỏ cua: Thách thức và chiến lược mưu sinh của dân di cư tự phát ở Tây Nguyên [A fish trapped in a basket of crabs: Challenges and survival strategies of spontaneous migrants in the Central Highlands], Journal of Folklore Culture, 6 .

Jackson, C. (2003). Gender analysis of land: beyond land rights for women?. Journal of Agrarian Change, 3 (4), 453-480. https://doi.org/10.1111/1471-0366.00062 
McCall, L. (2005). The complexity of intersectionality. Signs, 30 (3), 1771-1800. https://doi.org/ $10.1086 / 426800$

Ngo, T. P. L. (2015). Phong tục phân chia đất đai của người Chăm theo chế độ mẫu hệ trong bối cảnh bình đẳng giới hiện nay [Customs of land allocation among matrilineal groups of Cham people in the context of contemporary gender equality policies], Journal of Ethnology, 3.

Nightingale, A. (2011). Bounding difference: Intersectionality and the material production of gender, caste, class and environment in Nepal. Geoforum, 42 (2), 153-162. https://doi.org/ 10.1016/j.geoforum.2010.03.004

Ossome, L. (2014). Can the law secure women's rights to land in Africa? Revisiting tensions between culture and land commercialisation. Feminist Economics, 20 (1), 155-177. https:// doi.org/10.1080/13545701.2013.876506

Pain, A. \& Pema, D. (2004) The matrilineal inheritance of land in Bhutan, Contemporary South Asia, 13(4), 421-435. https://doi.org/10.1080/09584930500070654

Peters, P. (2002). Bewitching land: the role of land disputes in converting kin to strangers and in class formation in Malawi. Journal of Southern African Studies, 28 (1), 155-178. https:// doi.org/10.1080/03057070120117024

Peters, P (2013). Conflicts over land and threats to customary tenure in Africa today. African Affairs, 112 (449), 543-562.

Phan, H.P. (2018). Gendered access to resources in the context of REDD+: A case study from the Central Highlands, Vietnam. Unpublished $\mathrm{PhD}$ dissertation. University of East Anglia: Norwich.

Phung, T. Q. (1973). Lạc quan trên miền Thuợng [Being happy on the uplands], Part 1 Chapter 2. Retrieved from http://www.simonhoadalat.com/diaphan/truyengiao/lacquanmienthuong/ Phan2Chuong1.htm

Rao, N. (2011). Women's access to land: an Asian perspective. Expert Group Meeting: Enabling rural women's economic empowerment: institutions, opportunities and participation, UN Women, FAO, IFAD and WFP, Acca, Ghana, 20-23 September 2011.

RECOFTC (2014). Action Plan to prevent deforestation and forest degradation of Tong village, Lam Dong Province.

Ribot, J. \& Peluso, N. (2003). A theory of access. Rural Sociology, 68 (2), 153-181. https://doi.org/ 10.1111/j.1549-0831.2003.tb00133.x 
Rocheleau, D., Thomas-Slayter, B. P. \& Wangari, E. (1996). Feminist Political Ecology: Global issues and local experiences. London and New York: Routledge.

Rose, L. (2003). Women's Strategies for Customary Land Access in Swaziland and Malawi: A Comparative Study, Africa Today, 49 (2), 123-149. https://doi.org/10.1353/at.2003.0014

Standfield, D. (1984). Projects that title land in Central and South America and the Caribbean: expectations and problems. Land Tenure Centre Paper, Land Tenure Centre, University of Wisconsin, Madison, WI.

Truelove, Y. (2011). (Re-)conceptualising water inequality in Delhi, India through a Feminist Political Ecology framework. Geoforum, 42 (2), 163-172. https://doi.org/10.1016/ j.geoforum.2011.01.004

\section{ABSTRACT IN VIETNAMESE}

Bài viết này khám phá những quan điểm của phụ nữ về tiếp cận tài nguyên trong một cộng đồng mẫu hệ Tây Nguyên, Việt Nam. Các quyền thuộc về luật tục trong xã hội mẫu hệ không được hoàn toàn thừa nhận bởi Nhà nước, khi mà Nhà nước tăng cường sử dụng vũ lực để xác định quyền sở hữu đối với rừng và nhìn nhận khác biệt về hưởng dụng đất của hộ gia đình. Sử dụng các phương pháp định tính bao gồm phỏng vấn sâu, lịch sử cuộc đời, và quan sát, nghiên cứu này tập trung vào các chiến lược mà phụ nữ Cơ ho sử dụng để hưởng lợi từ những nguồn tài nguyên thiên nhiên chính như đất ruộng và đất rừng. Qua quan điểm của ba người phụ nữ với độ tuổi, tình trạng hôn nhân và nền tảng xã hội khác nhau, tôi chỉ ra cách thức mà quan hệ hôn nhân và họ hàng mẫu hệ tham gia vào tiếp cận tài nguyên của phụ nữ, trong bối cảnh tăng cường quản trị và kiểm soát của Nhà nước. Tôi sử dụng các tiếp cận liên biến (intersectional approach) của Sinh thái chính trị học nữ quyền (Feminist Political Ecology) (Rocheleau và đồng nghiệp, 1996), và lý thuyết tiếp cận của Ribot và Peluso (2003) để nhấn mạnh sự tương tác giữa giới, các cấu trúc mẫu hệ và nhân dạng xã hội trong việc định hình khả năng tiếp cận các tài nguyên thiên nhiên.

KEYWORDS tiếp cận tài nguyên của phụ nữ; xã hội mẫu hệ; liên biến; sinh thái chính trị học nữ quyền 